\title{
Root deformation affects mineral nutrition but not leaf gas exchange and growth of Genipa americana seedlings during the recovery phase after soil flooding
}

\author{
A deformação de raízes afeta a nutrição mineral mas não as trocas gasosas foliares e \\ o crescimento de mudas de Genipa americana durante a fase de recuperação após o \\ alagamento do solo
}

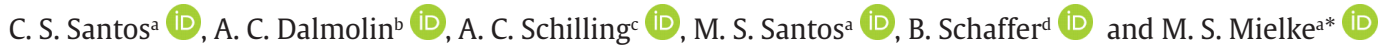 \\ aUniversidade Estadual de Santa Cruz - UESC, Departamento de Ciências Biológicas, Ilhéus, BA, Brasil \\ bUniversidade Federal do Sul da Bahia - UFSB, Centro de Formação em Ciências Agroflorestais, Ilhéus, BA, Brasil \\ 'Universidade Estadual de Santa Cruz - UESC, Departamento de Ciências Exatas e Tecnológicas, Ilhéus, BA, Brasil \\ dUniversity of Florida, Institute of Food and Agricultural Sciences - IFAS, Tropical Research and Education Center, Homestead, FL, USA
}

\begin{abstract}
Root deformation (RD) caused by errors in the pricking out process are irreversible and very difficult to detect in container-grown seedlings at the time of planting in the field. The objective of this study was to evaluate the effects of RD on leaf gas exchange, growth, biomass allocation and mineral nutrition of $G$. americana seedlings during the recovery phase after soil flooding. Four-months-old seedlings, with and without $\mathrm{RD}$, were flooded for 42 days and their recovery was evaluated 28 days after soil drainage. There were no significant interactions between RD and soil flooding for all leaf gas exchange, growth and mineral nutrition after soil drainage, with the exception of leaf $\mathrm{P}$ concentrations. In plants with no RD, the P concentration in leaves of non-flooded plants was significantly higher than that of plants with RD. Soil flooding and RD did not influence leaf or root N concentrations or whole-plant $\mathrm{N}$ content. RD increased the K concentration in the roots, but not in the leaves. Changes in the nutrient concentrations in leaves and roots indicate that RD may affect physiological performance of seedlings after planting in the field.

Keywords: environmental stress, macronutrients, pricking out, tropical trees.

Resumo

A deformação da raiz (RD) causada por erros no processo de repicagem é irreversível e difícil de detectar em mudas produzidas em embalagens no momento do plantio no campo. O objetivo deste estudo foi avaliar os efeitos do RD nas trocas gasosas foliares, crescimento, alocação de biomassa e nutrição mineral de mudas de G. americana na fase de recuperação após o alagamento do solo. Mudas com quatro meses de idade, com e sem RD, foram alagadas por 42 dias e a sua recuperação foi avaliada 28 dias após a drenagem do solo. Não houve interação significativa entre RD e alagamento do solo nas trocas gasosas foliares, crescimento e nutrição mineral após a drenagem, com exceção das concentrações de P foliar. Em plantas sem RD, a concentração de P nas folhas de plantas não alagadas foi significativamente maior que a das plantas com RD. $\mathrm{O}$ alagamento do solo e a RD não influenciaram as concentrações de $\mathrm{N}$ nas folhas e raízes, e no conteúdo de $\mathrm{N}$ na planta inteira. A RD aumentou a concentração de $\mathrm{K}$ nas raízes, mas não nas folhas. Alterações nas concentrações de nutrientes nas folhas e raízes indicam que a RD pode afetar o desempenho fisiológico das mudas após o plantio no campo.
\end{abstract}

Palavras-chave: estresse ambiente, macronutrientes, repicagem, árvores tropicais.

\section{Introduction'}

The Brazilian Atlantic Rainforest, one of the world's largest centers of biodiversity, has been increasingly impacted by forest degradation, habitat fragmentation and loss of forest cover as a result of anthropogenic disturbances. The production and planting of native tree seedlings has been widely used in the Brazilian Atlantic Rainforest to help restore degraded habitats (Silva et al., 2017). Due to environmental variations in terms of water, nutrition and light availability, production of high-quality seedlings of native tree species is essential to guarantee plant establishment for restore forest degraded areas (Harrison et al., 2008; Haase and Davis, 2017).

Seedling quality depends on the genetic sources and management procedures in the nursery. Root deformation

*e-mail: msmielke@uesc.br

Received: February 13, 2020 - Accepted: August 20, 2020 
(RD) diminishes seedling quality, reducing survival and growth in the field (Lindström and Rune, 1999). In container-grown seedlings, RD often occurs because errors that occur when seedlings are transferred from the seedbed to the containers in the nursery, a process known as pricking out (Wightman, 1999; Jaenicke, 1999; Hall, 2003; Dumroese et al., 2009; Gregorio et al., 2010; Wilkinson et al., 2014). RD caused by errors in the pricking out process are irreversible and very difficult to detect in container-grown seedlings, even at the time of planting in the field. The deleterious effects of RD incurred due to errors in the pricking out process have been described in some cultivated tree species, such as Coffea arabica (Mesquita et al., 2016) and Ilex paraguariensis (Medrado et al., 2002), but studies of how this damage affects the physiological performance of plants are lacking. Also, we are aware of no studies quantifying the effects of this type of RD on physiology and growth of tropical tree seedlings subjected to soil flooding.

Soil flooding decreases the availability of oxygen in the soil, leading to conditions of hypoxia or anoxia, which affects the soil redox potential (Eh) (Pezeshki and DeLaune, 2012). When oxygen content in the root zone is low, such as when roots are flooded for a specific length of time, there is a decrease in water and nutrient absorption and transport in plants as a result of an inhibition of root respiration and root damage (Martínez-Alcántara et al., 2012). This root damage may decrease root and stem hydraulic conductivity and inhibit leaf gas exchange (Drew, 1997). Flood-tolerant tree species have physiological, anatomical and/or morphological adaptations to flooding stress (Kozlowski, 2002). For example, tree seedlings tolerant to soil flooding often develop adventitious roots, hyperthophied stem lenticels, and/or a proliferation of aerenchyma in the xylem, which allow the exchange of gases between the roots and the atmosphere (Larson et al., 1993; Wang and Cao, 2012). In addition, flood-tolerant tree seedlings maintain relatively high rates of net photosynthesis, allowing carbon uptake and maintenance of growth under flooded soil conditions (Mielke et al., 2003; Dalmolin et al., 2013; Argus et al., 2015). Such changes allow these species to survive for long periods when their roots are submerged (Mielke et al., 2003). Despite the ability of some tree seedlings to survive soil flooding, physiological and growth responses after soil drainage are very variable among species (Ortuño et al., 2007; Mielke and Schaffer, 2010; Queiroz-Alves et al., 2019).

The absorption and transport of mineral nutrients in plants occurs mainly through mass flow and depends on the water potential gradient from leaves to the roots generated by transpiration and efficiency in the xylem hydraulic conductivity (Nobel, 2009). Thus, changes in the stomatal conductance to water vapor (gs) and transpiration (E) in plants subjected to soil flooding can cause insufficient transport of nutrients from the roots to the leaves, resulting in deficiencies of $\mathrm{N}$ and $\mathrm{P}$ (Kreuzwieser and Gessler, 2010), which are involved in the photosynthetic process (Nobel, 2009; Marschner, 2012). In plants, the cost of absorption and storage of mineral nutrients in organic molecules is highly nutrient dependent. Whereas P and $\mathrm{K}$ can be stored in the cell in inorganic forms, $\mathrm{N}$ is stored as amino acids or proteins, requiring higher metabolic costs (Chapin III et al., 1990). In flooded soils, a decrease in Eh may favor the reduction of $\mathrm{Fe}^{3+}$ and $\mathrm{Mn}^{4+}$ oxides and the release of cations (e.g., $\mathrm{P}, \mathrm{Mg}$ and $\mathrm{K}$ ) adsorbed on the surface of the oxides, contributing to an increase of some nutrients in the soil solution (Vahl, 1991). Despite the higher availability of some nutrients in flooded soils, nutrient deficiency in flooded plants is associated with lower energetic load (less ATP) produced when aerobic root metabolism shifts to the anaerobic fermentation pathway, accumulation of toxic substances, and reduction of the absorption surface caused by root death (Drew, 1997; Kozlowski, 2002).

Genipa americana L., Rubiaceae, is a tropical tree species native to Brazil, found in coastal areas of humid and subtropical climates (Andrade et al., 1999). It easily adapts to various types of climates and soils and is considered a flooded-tolerant species (Andrade et al., 1999; Mielke et al., 2003; Lavinsky et al., 2007). Due to its tolerance to soil flooding, G. americana has been recommended for restoration of riparian forests (Mielke et al., 2003). Although G. americana seedlings are tolerant of soil flooding, there are no studies reporting physiological, growth and nutritional responses of this species after soil drainage. The objective of this study was to evaluate the effects of $\mathrm{RD}$ on leaf gas exchange, growth, biomass allocation and mineral nutrition of $G$. americana seedlings during the recovery phase after soil flooding. The hypothesis tested was that RD and soil flooding have interactive effects on leaf gas exchange, growth, biomass allocation and absorption and distribution of nutrients in G. americana seedlings.

\section{Material and Methods}

\subsection{Study site and plant material}

This study was conducted at the Universidade Estadual de Santa Cruz (UESC) located in Ilhéus, Bahia, Brazil (39¹3'59"O; $14^{\circ} 45^{\prime} 15^{\prime \prime} \mathrm{S}$ ). The seeds were obtained from fruit purchased at fairgrounds in the municipalities of Buerarema (39 $18^{\prime} 00^{\prime \prime} \mathrm{W}, 14^{\circ} 57^{\prime} 32^{\prime \prime}$ ) and São José da Vitória (39²0’20”W, $15^{\circ} 05^{\prime} \mathrm{W}^{\prime} 02^{\prime}$ ”S), Bahia, Brazil. The fruit were manually pulped and washed in running tap water. After washing, the seeds were dried in the shade on paper towels for 24 hours, and then germinated in seedbeds for 55 days. One hundred seedlings, four centimeters in length with cotyledon leaves fully expanded, were transferred from the seedbeds to 1.5 -L plastic bags containing forest soil as a substrate. At the time of pricking out, two root conditions were induced: normal roots (control treatment) (Figure 1A) and deformed roots (RD treatment) (Figure $1 \mathrm{~B}$ and $1 \mathrm{C}$ ). RD was induced manually in $50 \%$ of the seedlings by creating a plant hole with a depth that was $50 \%$ shallower than the total root length in the substrate. In the control treatment, root holes were dug in the substrate to a depth that was a little deeper than the total root length. The plastic bags were then placed in solid PVC tubes (100 mm diameter $\times 250 \mathrm{~mm}$ height), with two opposite holes at the bottom to allow water drainage. One seedling per plastic bag was placed in each PVC tube. The experiment was started 129 days (or about four months) after the seedlings were transferred 


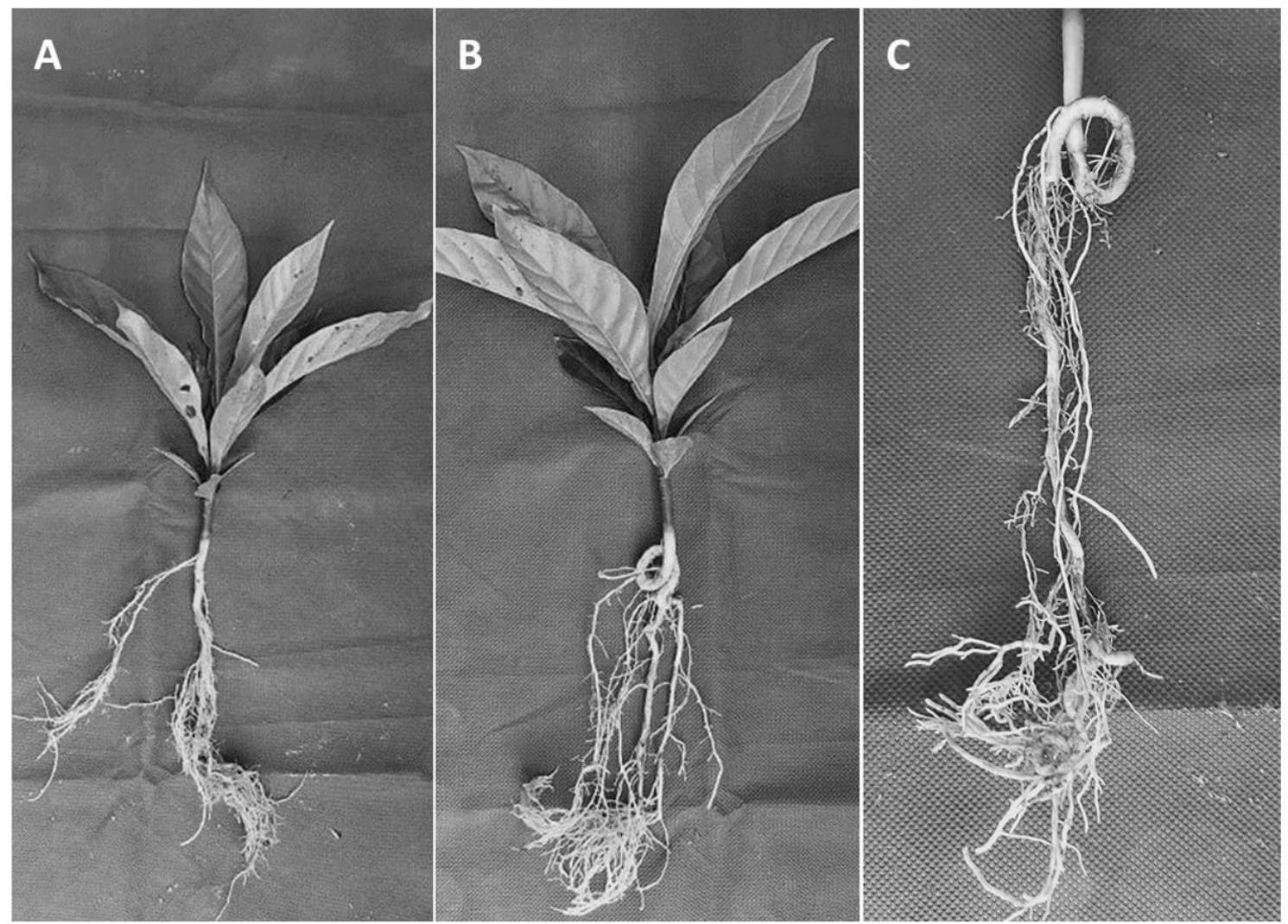

Figure 1. Four months old seedlings of G. americana without (A) and with (B) root deformation (RD) caused by errors in the pricking out process, and a detail of the RD (C).

from seedbeds to the plastic bags (pricking out process). At that time, the holes at the bottom of PVC tubes were capped using rubber stoppers and $50 \%$ of the seedlings in the control treatment and $50 \%$ of the seedlings in the RD treatment were flooded using tap water. The remaining $50 \%$ of the seedlings in each root treatment were not flooded. Soil flooding lasted 42 days. At the end of the flooding period, $50 \%$ of the flooded and $50 \%$ of the non-flooded seedlings were harvested. At that time, the water of the flooded plants was drained, and a second evaluation was performed at 28 days after drainage (recovery).

\subsection{Soil analysis}

The soil analysis was conducted in the Plant Soil Analysis Laboratory of the Centro de Pesquisas do Cacau (CEPEC/CEPLAC), Ilhéus, BA, Brazil. Soil pH was 5.8, the cation exchange capacity (CEC) was $19.3 \mathrm{cmol}_{c} / \mathrm{dm}^{3}$, soil N content was $3.5 \mathrm{~g} \mathrm{dm}^{-2}$, P content was $51 \mathrm{mg} \mathrm{kg}^{-1}$, K content was $0.52 \mathrm{cmol}_{\mathrm{c}} / \mathrm{dm}^{3}$, and $\mathrm{Mg}$ content was $3.5 \mathrm{cmol}_{\mathrm{c}} / \mathrm{dm}^{3}$.

\subsection{Soil redox potential and microclimate}

At the time of seedling planting in plastic bags, one access PVC tube with a $15 \mathrm{~mm}$ diameter and $200 \mathrm{~mm}$ in length was inserted into the middle third of the substrate of 18 bags with seedlings, nine in the RD treatment and nine in the control treatment. The bottom half of each access tube had a perforations allowing it to be filled with the substrate solution. The sensor for soil redox potential
(Eh) measurements was inserted into the access tubes. Soil Eh was measured weekly with a pH/ORP Meter 8651 (AZ Instrument Corp., Taiwan, China) at 2, 7, 14, 30 and 40 days after soil flooding. Air temperature and relative humidity $(\mathrm{RH})$ were monitored inside the nursery with a Hobo Pro V2 Data Logger sensor (Onset Computer, Bourne, Massachusetts, USA). From the air temperature and RH the air vapor pressure deficit was calculated. During the experiment, the mean day and night temperatures were $27.7{ }^{\circ} \mathrm{C}$ and $23.0{ }^{\circ} \mathrm{C}$, respectively. The mean daily and mean maximum vapor pressure deficit was $0.81 \mathrm{kPa}$ and $2.15 \mathrm{kPa}$, respectively.

\subsection{Leaf gas exchange}

Net photosynthesis (A) and stomatal conductance to water vapor (gs) were measured in nine plants (replicates) per treatment combination at the end of each period (flooding and recovery periods) with a Li-6400XT infrared gas analyzer (Li-Cor, Lincoln, Nebraska, USA) equipped with a 6400-02B artificial light source. Measurements were made on a mature and completely expanded leaf, always between 8 and $11 \mathrm{~h}$. The measurements were done under artificial photosynthetically active radiation (PAR) of $1000 \mu \mathrm{mol}$ photons $\mathrm{m}^{-2} \mathrm{~s}^{-1}$ at the adaxial leaf surface and a reference $\mathrm{CO}_{2}$ concentration of air flowing into the leaf cuvette of 390 $\pm 10 \mu \mathrm{mol} \mathrm{CO}_{2} \mathrm{~mol}^{-1}$ air. During the measurements, the leaf chamber temperature was maintained at $28 \pm 1{ }^{\circ} \mathrm{C}$ and the relative humidity $65 \pm 5 \%$. 


\subsection{Plant growth}

At the beginning of the experiment, the dry mass of roots (RDM), stems (SDM), leaves (LDM) and total leaf area (LA) were measured for nine plants with and without RD. At the end of flooding and recovery periods, the same variables were measured for nine plants per treatment combination. For dry mass determination, plants were harvested, washed, separated into root, stem and leaves and dried in a forced ventilation oven at $50{ }^{\circ} \mathrm{C}$ to a constant mass. Total plant dry mass was calculated by summing RDM, SDM and LDM for each seedling. The LA of each plant was measured with an LI-3100 leaf area meter (Li-Cor, Lincoln, Nebraska, USA). From these values, the following variables were calculated according Hunt (2017): leaf area ratio (LAR = LA/TDM), relative growth rate $\left[R G R=\left(1 \mathrm{nTDM}_{1}-1 \mathrm{nTDM}_{0}\right) / \mathrm{t}\right]$ and net assimilation rate $\left[\mathrm{NAR}=\left(\mathrm{TDM}_{1}-\mathrm{TDM}_{0}\right) /\left(\mathrm{LA}_{1}-\mathrm{LA}_{0}\right) \times\right.$ $\left.\left(\operatorname{lnL} A_{1}-\operatorname{lnL} A_{0}\right) / t\right]$, where $\mathrm{TDM}_{1}$ and $\mathrm{TDM}_{0}$ are total dry mass at end of experiment and initial total dry mass; LA $_{1}$ and $\mathrm{LA}_{0}$ correspond to the final and initial total leaf areas. We also calculated the leaf area to root dry mass ratio (LA/ $\mathrm{RDM})$ and the root dry mass to shoot dry mass ratio (R/S), in which the shoot dry mass is the sum of LDM + SDM.

\subsection{Plant macronutrient content}

At the end of the recovery period, after drying the plant tissues in a forced ventilation oven at $50{ }^{\circ} \mathrm{C}$ to a constant mass, the samples were milled in a ball mill. All macronutrient analyses were done at the Plant Tissue Analysis Laboratory of the Cacao Research Center (CEPEC/CEPLAC), following the procedures described in Embrapa (2009). A $200 \mathrm{mg}$ sample was used for analysis of macronutrient concentrations. Concentrations of nitrogen (N) were determined by the Kjeldahl destilation method using a destilator model TE0364 (Tecnal, São Paulo, Brazil). The concentrations of potassium $(\mathrm{K})$ were determined in the extract after a nitric-perchloric digestion using a flame photometer B464 (Micronal SA, São Paulo, Brazil). The concentrations of phosphorus $(\mathrm{P})$ was determined using a spectrophotometer EEQ9005 (Edutec, Brazil).

\subsection{Data analysis}

The experiment was arranged in a completely randomized design in a $2 \times 2$ factorial arrangement with flooding treatment (flooded or non-flooded) as one factor and root deformation (RD or control with no RD) as the other factor, with 9 plants (replicates) for each treatment combination, totaling 36 plants were evaluated during the flooding and recovery periods. All data were analyzed by analysis of variance (ANOVA) followed by a Tukey's Honestly Significant Difference (HSD) test at a 5\% significance level using R statistical software (R Core Team, 2015).

\section{Results}

Throughout the 42 days of flooding, the average Eh of the soil solution decreased rapidly for plants without and with RD, although the decreases in Eh were much more pronounced in plants with RD than in the plants without RD during the first week after flooding. Two and seven days after flooding the values of Eh for plants without and with RD were, respectively, $10.59 \pm 38.22 \mathrm{mV}$ and $-161.41 \pm 15.68 \mathrm{mV}$, and $-28.92 \pm 35.55 \mathrm{mV}$ and $-196.40 \pm 18.53 \mathrm{mV}$. Fourteen days after flooding, the Eh remained stable until plants were unflooded and Eh was similar between plants without RD $(-240.67 \pm 6.14 \mathrm{mV})$ and with $\mathrm{RD}(-237.77 \pm 9.76 \mathrm{mV})$. We observed the appearance of hypertrophied stem lenticels and adventitious roots in the flooded plants. In addition, some flooded plants, both with or without RD, exhibited chlorosis and foliar abscission.

At the end of the flooding period, gs and A of non-flooded plants were about 2-fold higher of that of the flooded plants $(\mathrm{p}<0.001$; Table 1). Plant growth and biomass allocation variables (RGR, NAR, LA and LAR) were not significantly influenced $(p>0.05)$ by RD or soil flooding and there was no statistically significant interaction ( $p>0.05)$ between RD and soil flooding. At the end of the recovery period, there was no significant effect ( $p>0.05$ ) of RD on any growth, biomass allocation or leaf gas exchange variables. Significant effects of soil flooding were observed for gs ( $p<0.05$ ), RGR and NAR ( $p<0.01$ ), LAR ( $p<0.05)$, and LA/RDM and $\mathrm{R} / \mathrm{S}(\mathrm{p}<0.001)$. The mean values of gs, LAR and LA/RDM were, respectively, about 1.1, 1.2 and 1.6-fold higher in flooded than in non-flooded plants, whereas RGR, NAR and R/S were, respectively, about 2.3, 2.2, 1.6-fold higher in non-flooded than in flooded plants.

The RD and soil flooding did not affect the $\mathrm{N}$ concentration in leaves and roots ( $p>0.05$ ) (Table 2 ), and a non-significant interaction between $\mathrm{RD}$ and soil flooding for $\mathrm{N}$ concentration in leaves and roots $(\mathrm{p}>0.05)$ were observed. No significant effect of RD on the root or leaf $P$ concentration was observed ( $p>0.05$, ANOVA). There was a significant effect of soil flooding on the concentration of $P$ in leaves $(p<0.001)$. The $P$ content in leaves was approximately 2.6 -fold higher in non-flooded than in flooded plants. In addition, a significant interaction between RD and soil flooding for P concentration in leaves $(\mathrm{p}<0.05)$ was observed. In plants with no RD, the P concentration in leaves of non-flooded plants was significantly higher than that of plants with $R D(p<0.05)$ (Figure 2$)$. Regardless of the root condition, the $P$ concentration in non-flooded plants was significantly higher than in non-flooded plants. The RD did not affect the K concentration in leaves $(p>0.05)$; but there were significant effects of RD on the K concentration in roots ( $\mathrm{p}<0.001$ ) (Table 2$)$. The $K$ concentration was 3.7-fold higher in the roots of plants with RD than in those with no RD. Also, there was a significant effect of soil flooding on $K$ concentration in leaves $(p<0.01)$. The $K$ concentration in leaves of non-flooded plants was 1.3-fold higher than in leaves of flooded plants.

The whole plant contents (roots + stems + leaves) of $\mathrm{N}$ was not significantly influenced $(p>0.05)$ by RD or soil flooding (Table 3 ). However, the $\mathrm{K}$ content in plants with RD was significantly higher $(\mathrm{p}<0.001)$ than in plants without RD. The K content was about 1.7-fold higher in plants with RD compared to plants without RD. The plant contents of $\mathrm{P}$ and $\mathrm{K}$ were significantly affected by soil flooding ( $\mathrm{p}<0.05$ ). The whole plant contents of $\mathrm{P}$ and $\mathrm{K}$ were about 1.9-fold and 1.4-fold higher, respectively in the non-flooded plants in relation to the flooded plants. 
Table 1. Means and significant levels of a two-way ANOVA comparing effects of root deformation (RD) and soil flooding on leaf gas exchange, growth and biomass allocation for seedlings of G. americana at the end of the flooding period (42 days) and recovery (28 days). $\mathrm{N}=9$.

\begin{tabular}{|c|c|c|c|c|c|c|c|c|}
\hline & \multirow{2}{*}{ Variable } & \multicolumn{2}{|c|}{$\operatorname{Root}(\mathrm{R})$} & \multicolumn{2}{|c|}{ Flooding (F) } & \multicolumn{3}{|c|}{ ANOVA } \\
\hline & & Without RD & With RD & Non-flooding & Flooding & $\mathbf{R}$ & $\mathbf{F}$ & $\mathbf{R} \times \mathbf{F}$ \\
\hline \multirow{8}{*}{ Flooding } & gs & $0.13 \pm 0.02$ & $0.16 \pm 0.02$ & $0.19 \pm 0.03$ & $0.10 \pm 0.03$ & \pm & $* * *$ & ns \\
\hline & A & $7.25 \pm 0.60$ & $7.06 \pm 0.70$ & $9.35 \pm 0.68$ & $4.96 \pm 0.84$ & ns & $* * *$ & ns \\
\hline & RGR & $17.22 \pm 1.94$ & $14.43 \pm 1.89$ & $16.96 \pm 3.18$ & $14.74 \pm 3.19$ & ns & ns & ns \\
\hline & NAR & $0.46 \pm 0.08$ & $0.38 \pm 0.07$ & $0.39 \pm 0.11$ & $0.45 \pm 0.10$ & ns & ns & ns \\
\hline & LA & $378.5 \pm 28.6$ & $384.8 \pm 17.5$ & $392.5 \pm 17.8$ & $370.5 \pm 11.1$ & ns & ns & ns \\
\hline & LAR & $0.30 \pm 0.04$ & $0.37 \pm 0.02$ & $0.32 \pm 0.04$ & $0.34 \pm 0.05$ & ns & ns & ns \\
\hline & LA/RDM & $0.91 \pm 21.25$ & $1.01 \pm 14.01$ & $0.89 \pm 16.99$ & $1.03 \pm 15.93$ & ns & ns & ns \\
\hline & $\mathrm{R} / \mathrm{S}$ & $0.64 \pm 0.12$ & $0.70 \pm 0.08$ & $0.77 \pm 0.10$ & $0.57 \pm 0.07$ & ns & $*$ & ns \\
\hline \multirow{8}{*}{ Recovery } & gs & $0.17 \pm 0.01$ & $0.17 \pm 0.01$ & $0.16 \pm 0.01$ & $0.18 \pm 0.01$ & ns & $*$ & ns \\
\hline & A & $9.03 \pm 0.50$ & $8.61 \pm 0.45$ & $8.9 \pm 0.28$ & $8.97 \pm 0.24$ & ns & ns & ns \\
\hline & RGR & $10.06 \pm 1.76$ & $9.29 \pm 2.98$ & $13.53 \pm 1.33$ & $5.83 \pm 2.17$ & ns & $* *$ & ns \\
\hline & NAR & $0.42 \pm 0.09$ & $0.32 \pm 0.12$ & $0.51 \pm 0.06$ & $0.23 \pm 0.08$ & ns & $* *$ & ns \\
\hline & LA & $392.7 \pm 14.1$ & $393.7 \pm 29.8$ & $383.7 \pm 10.3$ & $402.7 \pm 17.4$ & ns & ns & ns \\
\hline & LAR & $0.23 \pm 0.01$ & $0.27 \pm 0.03$ & $0.23 \pm 0.01$ & $0.27 \pm 0.03$ & ns & $*$ & ns \\
\hline & LA/RDM & $0.64 \pm 2.68$ & $0.69 \pm 10.38$ & $0.50 \pm 5.26$ & $0.81 \pm 10.18$ & ns & $* * *$ & ns \\
\hline & $\mathrm{R} / \mathrm{S}$ & $0.70 \pm 0.05$ & $0.78 \pm 0.07$ & $0.90 \pm 0.12$ & $0.58 \pm 0.05$ & ns & $* * *$ & ns \\
\hline
\end{tabular}

$\mathrm{p}>0.05(\mathrm{~ns}), \mathrm{p}<0.05\left(^{*}\right), \mathrm{p}<0.01\left({ }^{* *}\right), \mathrm{p}<0.001\left({ }^{* * *}\right)$. Abbreviations: gs = stomatal conductance to water vapor $\left(\right.$ mol $\left.\mathrm{m}^{-2} \mathrm{~s}^{-1}\right) ; \mathrm{A}=\mathrm{net}_{\mathrm{photosynthetic}}$ rate $\left(\mu \mathrm{mol} \mathrm{m} \mathrm{m}^{-2} \mathrm{~s}^{-1}\right) ; \mathrm{RGR}=$ relative growth rate $\left(\mathrm{mg} \mathrm{g}^{-1}\right.$ day $\left.{ }^{-1}\right) ; \mathrm{NAR}=$ net assimilatioin rate $\left(\mathrm{mg} \mathrm{cm}^{-2} \mathrm{day}^{-1}\right) ; \mathrm{LA}=$ leaf area $\left(\mathrm{cm}^{2}\right) ; \mathrm{LAR}=1$ leaf area ratio $\left(\mathrm{dm}^{2} \mathrm{~g}^{-1}\right) ; \mathrm{RDM}=$ dry mass of roots $(\mathrm{gr}) ; \mathrm{RM}=\operatorname{root}$ mass $(\mathrm{g}) ; \mathrm{SM}=$ shoot mass $(\mathrm{g}) ; \mathrm{R} / \mathrm{S}=$ root dry mass to shoot dry mass ratio.

Table 2. Means and significance levels of a two-way ANOVA comparing effects of root deformation (RD) and soil flooding on concentrations $\left(\mathrm{g} \mathrm{kg}^{-1}\right)$ on N, P, and $\mathrm{K}$ in leaves and roots of concentrations of these nutrients in seedlings of G. americana after 28 days of soil drainage (recovery). $\mathrm{N}=3$.

\begin{tabular}{|c|c|c|c|c|c|c|c|c|}
\hline & & \multicolumn{2}{|c|}{$\operatorname{Root}(\mathbf{R})$} & \multicolumn{2}{|c|}{ Flooding (F) } & \multicolumn{3}{|c|}{ ANOVA } \\
\hline & & Without RD & With RD & Non-flooding & Flooding & $\mathbf{R}$ & $\mathbf{F}$ & $\mathbf{R} \times \mathbf{F}$ \\
\hline \multirow{3}{*}{ Leaves } & $\mathrm{N}$ & $10.40 \pm 0.29$ & $11.10 \pm 0.18$ & $10.78 \pm 0.26$ & $10.73 \pm 0.29$ & ns & ns & ns \\
\hline & $\mathrm{P}$ & $4.05 \pm 0.82$ & $3.68 \pm 0.53$ & $5.61 \pm 0.33$ & $2.12 \pm 0.20$ & ns & $* * *$ & $*$ \\
\hline & K & $10.40 \pm 0.77$ & $11.14 \pm 0.47$ & $12.19 \pm 0.34$ & $9.35 \pm 0.46$ & ns & $* *$ & ns \\
\hline \multirow{3}{*}{ Roots } & $\mathrm{N}$ & $5.18 \pm 0.45$ & $5.95 \pm 0.17$ & $5.23 \pm 0.43$ & $5.90 \pm 0.24$ & ns & ns & ns \\
\hline & $\mathrm{P}$ & $2.16 \pm 0.15$ & $2.57 \pm 0.12$ & $2.53 \pm 0.13$ & $2.20 \pm 0.16$ & ns & ns & ns \\
\hline & K & $5.00 \pm 0.21$ & $18.16 \pm 1.07$ & $12.60 \pm 2.83$ & $10.55 \pm 2.05$ & $* * *$ & ns & ns \\
\hline
\end{tabular}

$\mathrm{p}>0.05(\mathrm{~ns}), \mathrm{p}<0.05\left(^{*}\right), \mathrm{p}<0.01\left(^{* *}\right), \mathrm{p}<0.001\left(^{* * *}\right)$.

There were no interactive effects between RD and soil flooding for the whole plant contents of any macronutrient.

\section{Discussion}

All plants with and without RD survived the soil flooding and recovery periods, demonstrating the tolerance of $G$. americana seedlings to soil flooding, as previously reported by Andrade et al. (1999), Mielke et al. (2003) and Lavinsky et al. (2007). However, the recovery phase after flooding has never been assessed for this species. In the present experiment, leaf gas exchange variables returned to the values similar to those of non-flooded plants and gs was 1.1 -fold higher in flooded than in non-flooded plants at the end of the recovery period. The fact that plants removed from flooded soil could not resume growth at the end of recovery period may be related to the short period of time after drainage (28 days), which did not allow sufficient time for flooded plants to resume normal growth rates. However, the reestablishment of pre-flood A and gs values indicated the recovery of the photosynthetic activity (Voesenek and Bailey-Serres, 2015).

When soil is flooded, the equilibrium state of soil elements and compounds is altered, leading to changes in soil physical, chemical and biological properties, the 
most significant being a decrease in soil Eh (Pezeshki and DeLaune, 2012). When Eh decreases, a greater demand for oxygen occurs, causing an additional stress to the roots (Pezeshki, 2001). Plants adapted to constantly flooded environments have morphological and anatomical adaptations that allow the aeration of the rhizosphere, as the presence of lenticels and aerenchyma (Kozlowski, 2002). For the G. americana seedlings, a more abrupt decrease in the soil Eh in the first week after flooding was observed for plants with RD. This fact may indicate that these plants had larger restrictions to the diffusion of gases from the atmosphere to the soil than the plants without $\mathrm{RD}$. However, the Eh values were quite similar between the plants with and without RD from the second week after soil flooding. In addition, the absence of significant effects of RD on RGR and NAR between non-flooded and flooded plants at the end of flooding period may be related to the morphological and anatomical changes, which may have supplanted the effects of RD on seedlings of this species.

A decrease in $\mathrm{N}$ concentrations in tree seedlings subjected to soil flooding has been reported for many tree species (Martínez-Alcántara et al., 2012; Bidalia et al., 2018; Ow et al., 2019). Decreases in N concentrations in leaves of tree seedlings appears to be associated with decreased

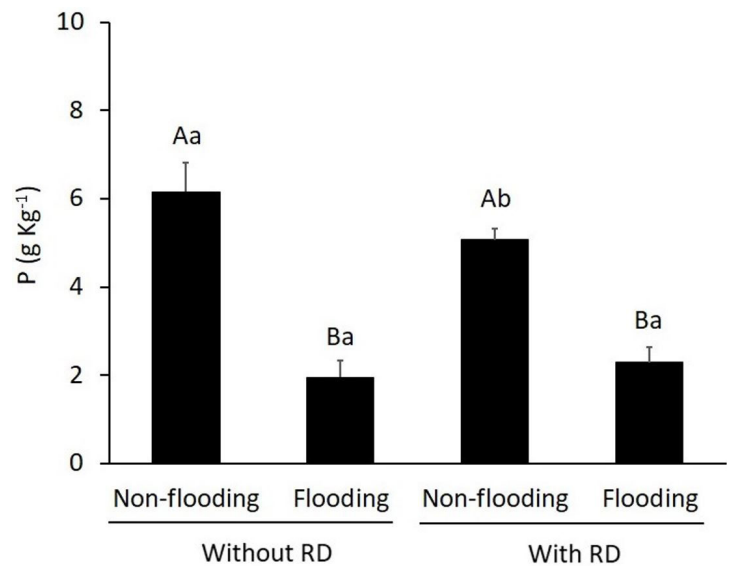

Figure 2. Concentrations of $P$ in leaves for $G$. americana seedlings without or with root deformation (RD) after 28 days of soil drainage (recovery). $\mathrm{N}=3$. Means followed by the same letter are not significantly different according to Tukey's test $(\mathrm{p}<0.05)$. Capital letters represent comparisons water effects within root conditions and lower case letters represent comparisons of roots effects within water conditions. gs and $\mathrm{E}$, which is a common response in plants subjected to soil flooding (Mielke et al., 2003; Lavinsky et al., 2007; Herrera et al., 2008; Mielke and Schaffer, 2010; Dalmolin et al., 2013). In our experiment, even if there was a decrease in gs in flooded plants, at 28 days after soil drainage the values of gs were 1.13-fold higher in flooded plants than in non-flooded plants, maybe maintaining a high mass flow rate to the leaves. In addition, the energy demand for the uptake and assimilation of $\mathrm{N}$ in the roots is very high (Marschner, 2012). Roots subjected to anoxic conditions tend to produce less energy in the form of ATP, impairing soil N absorption and assimilation (Larson et al., 1992; Rennenberg et al., 2009). Thus, considering that the $\mathrm{N}$ content in plants is fundamental for the maintenance of several metabolic processes, the non-significant differences in the concentrations of $\mathrm{N}$ in leaves and roots between flooded and non-flooded $G$. americana seedlings corroborates the high tolerance to soil flooding of this species (Andrade et al., 1999; Mielke et al., 2003; Lavinsky et al., 2007).

Significant declines in P absorption by tropical trees subjected to soil flooding have been reported (Bidalia et al., 2018). The low availability of P induces increases in the root surface area, through lateral root emission and root length, leading to increases in R/S ratio (Shen et al., 2011; Péret et al., 2014). The low $P$ concentrations in the leaves of $G$. americana seedlings subjected to soil flooding may be related to the reduction of carbon allocated to the roots, evidenced by the decrease of the R/S ratio for P. Although there was no significant difference between the P concentrations in the leaves and roots of plants with and without RD, the concentration of $P$ in the leaves of plants without RD was 1.1-fold higher than in plants with RD. In addition, the P concentration was 1.2-fold higher in the roots of plants with RD compared to plants without RD. These results are evidence that $\mathrm{RD}$ caused an impairment to the transport of $\mathrm{P}$ from roots to the leaves. The significant differences between $P$ concentrations in leaves of non-flooded plants with and without RD indicate that alternating periods of soil flooding may enhance the deficiency of this macronutrient in leaves of seedlings with RD.

After N, K is the most abundant macronutrient in plants with a broad action in plant metabolism, being very important in several physiological processes, including enzyme activation, cell expansion, osmoregulation, stomatal movement (Nobel, 2009; Hasanuzzaman et al., 2018) and differentiation of xylem vessels (Frensch and Hsiao, 1993;

Table 3. Means and significant levels of a two-way ANOVA comparing effects of root deformation (RD) and soil flooding (F) on whole plant contents $(\mathrm{mg})$ of $\mathrm{N}, \mathrm{P}$, and $\mathrm{K}$ in seedlings of $\mathrm{G}$. americana after 28 days of soil drainage (recovery). $\mathrm{N}=3$.

\begin{tabular}{|c|c|c|c|c|c|c|c|}
\hline & \multicolumn{2}{|c|}{ Root (R) } & \multicolumn{2}{|c|}{ Flooding (F) } & \multicolumn{3}{|c|}{ ANOVA } \\
\hline & Without RD & With RD & Non-flooding & Flooding & $\mathbf{R}$ & $\mathbf{F}$ & $\mathbf{R} \times \mathbf{F}$ \\
\hline $\mathrm{N}$ & $105.05 \pm 7.51$ & $99.57 \pm 5.66$ & $104.42 \pm 7.12$ & $100.20 \pm 6.34$ & ns & ns & ns \\
\hline $\mathrm{P}$ & $54.03 \pm 13.51$ & $43.60 \pm 9.13$ & $63.98 \pm 7.18$ & $33.65 \pm 7.22$ & ns & $* *$ & ns \\
\hline K & $109.06 \pm 9.07$ & $181.08 \pm 23.79$ & $167.12 \pm 29.72$ & $123.02 \pm 20.32$ & $* * *$ & $* *$ & ns \\
\hline
\end{tabular}

$\mathrm{p}>0.05(\mathrm{~ns}), \mathrm{p}<0.05\left(^{*}\right), \mathrm{p}<0.01\left(^{* *}\right), \mathrm{p}<0.001\left(^{* * *}\right)$. 
McCully, 1994). In the xylem, the accumulation of $\mathrm{K}$ increases the hydraulic conductivity (Nardini et al., 2010; Oddo et al., 2011). In our experiment, we observed that plants without RD had higher concentrations of $\mathrm{N}, \mathrm{P}$, and $\mathrm{K}$ in the leaves than in the roots. However, among the four macronutrients analyzed, only $\mathrm{K}$ had a $\mathrm{L} / \mathrm{R}$ ratio less than that of plants with RD. The large increase of K concentration in the roots may have been a compensatory response to slow transport of this nutrient to the aerial part of the plants. In addition, we suggest that hydraulic conductivity was altered by the RD. Although the effects of K concentrations on root hydraulics were not been analyzed in this study, we suggest that the high accumulation of this cation in deformed roots increases the hydraulic conductivity of the xylem, thus ensuring the maintenance of high values of leaf gas exchange. At whole plant scale, the higher demand for $\mathrm{K}$ in plants with RD (about 60\% higher than plants without RD) would result in a higher consumption of this macronutrient from the soil. Thus, because of the high demand for $\mathrm{K}$ it is possible that seedlings with RD may have severe deficiency over time, especially if adequate replacement of this macronutrient with fertilization is not performed.

In recent years, efforts have been being made to develop technologies for silvicultural management of native trees in Brazil (Rolim et al., 2019), but the great diversity of species and socioeconomic and cultural barriers still hinder the management of native tree species. In one of the few references focusing on the state of the art of native forest tree seedling production in Brazil, Silva et al. (2015) identified that the main problems for forest nursery management are the lack of training and low technical skills of employees, the difficulty of selling seedlings and the continuous supply of seeds. The RD caused by errors in pricking out the seedlings is associated with the lack of attention and training of the nursery technicians at a crucial stage of the forest seedling production process. During the pricking out process, a hole is dug in the substrate of the container that will receive the seedling. The hole should be deep enough to accommodate the roots and slightly larger than the main root. Soon after placing roots in the hole, the seedling should be lightly pulled upwards to straighten the main root and irrigated to bring the substrate closer to the roots to avoid the formation of air pockets (Jaenicke, 1999; Hall, 2003; Dumroese et al., 2009; Wilkinson et al., 2014). However, when the planting hole has a depth that is less than the length of the main root, root bending occurs (Hall, 2003; Dumroese et al., 2009). Root damage caused by error during the pricking out process is so common a problem that several manuals for seedling production in forest nurseries draw attention to it (Wightman, 1999; Jaenicke, 1999; Hall, 2003; Dumroese et al., 2009; Gregorio et al., 2010; Wilkinson et al., 2014), but experimental trials with tropical tree seedlings are scarce. G. americana is an important tropical tree species indicated as one of the 15 priority native species for silvicultural management in the Brazilian Atlantic Forest biome (Rolim et al., 2019). The fruits of this species are also widely consumed by native peoples in the form of liquor, candy or juice. Thus, its economic and social importance, as well as the ease of obtaining fruit and seeds and the high germination rates (Souza et al., 1999), make this species widely used in small and medium forest nurseries; where lack of training and low technical skills of employees is a serious and recurring problem.

In summary, to the best of our knowledge, this is the first experimental study analyzing the effects of RD induced by errors in the pricking out process and soil flooding on physiological, growth and nutritional responses of a tropical tree species. As expected, all G. americana seedlings survived 42 days of soil flooding and there were significant differences between flooded and non-flooded plants for A and gs. There were no significant interactions between $\mathrm{RD}$ and soil flooding for all leaf gas exchange, growth and mineral nutrition after soil drainage, with the exception of leaf P concentrations. Significant differences between flooded and non-flooded plants were observed for RGR, NAR, LAR and LA/RDM 28 days after soil drainage, despite the completely recovery of A and gs. RD did not affect the leaf gas exchange, growth and biomass allocation. RD and soil flooding did not influence the concentrations and whole plant contents of $\mathrm{N}$, but affected the concentrations and whole plant contents of $\mathrm{P}$ and $\mathrm{K}$. Although RD did not induce significant changes in leaf gas exchange and growth of four-month-old G. americana seedlings subjected to soil flooding, changes in the macronutrient concentrations in leaves and roots indicated that RD may affect physiological performance of seedlings after planting in the field.

\section{Acknowledgements}

This study was financed in part by the Coordenação de Aperfeiçoamento de Pessoal de Nível Superior Brasil (CAPES) - Finance Code 001. Funding for Catriane Sousa Santos was provided by scholarships from the Fundação de Amparo à Pesquisa do Estado da Bahia (BOL220/2018). Martielly S. dos Santos acknowledges the Brazilian National Council for Scientific and Technological Development (CNPq) for a post-doctoral fellowship (409947/2017-2). Marcelo S. Mielke gratefully acknowledges CNPq for a Fellowship of Scientific Productivity (305477/2018-8). We also thank Mr. Manoel Gomes de Souza and Gabriel Oliveira Santos for assisting with maintenance of the experiment.

\section{References}

ANDRADE, A.C.S., RAMOS, F.N., SOUZA, A.F., LOUREIRO, M.B.E. and BASTOS, R., 1999. Flooding effects in seedlings of Cytharexyllum myrianthum Cham. and Genipa americana L.: responses of two neotropical lowland tree species. Revista Brasileira de Botanica. Brazilian Journal of Botany, vol. 22, pp. 281-285. http://dx.doi. org/10.1590/S0100-84041999000500009.

ARGUS, R.E., COLMER, T.D. and GRIERSON, P.F., 2015. Early physiological flood tolerance is followed by slow postflooding root recovery in the dryland riparian tree Eucalyptus camaldulensis subsp. refulgens. Plant, Cell E Environment, vol. 38, no. 6, pp. 1189-1199. http://dx.doi.org/10.1111/pce.12473. PMid:25328049. 
BIDALIA, A., OKRAM, Z., HANIEF, M. and RAO, K.S., 2018. Assessment of tolerances in Mitragyna parviflora (Roxb.) Korth. And Syzigium cumini Keels: seedlings to waterlogging. Photosynthetica, vol. 56, no. 2, pp. 707-717. http://dx.doi.org/10.1007/s11099-017-0724-1.

CHAPIN III, F.S., SCHULZE, E.D. and MOONEY, H.A., 1990. The ecology and economics of storage in plants. Annual Review of Ecology and Systematics, vol. 21, no. 1, pp. 423-447. http:// dx.doi.org/10.1146/annurev.es.21.110190.002231.

DALMOLIN, A.C., DALMAGRO, H.J., LOBO, F.A., ANTUNES JUNIOR, M.Z., ORTÍZ, C.E.R. and VOURLITIS, G.L., 2013. Photosynthetic light and carbon dioxide response of the invasive tree, Vochysia divergens Pohl, to experimental flooding and shading. Photosynthetica, vol.51, no. 3, pp. 379-386. http://dx.doi.org/10.1007/s11099-013-0034-1.

DREW, M.C., 1997. Oxygen deficiency and root metabolism: injury and acclimation under hypoxia and anoxia. Annual Review of Plant Physiology and Plant Molecular Biology, vol. 48, no. 1, pp. 223-250. http://dx.doi.org/10.1146/annurev.arplant.48.1.223. PMid:15012263.

DUMROESE, R.K., LUNA, T. and LANDIS, T.D., 2009. Nursery manual for native plants: a guide for tribal nurseries: nursery management. Washington: U.S. Department of Agriculture, Forest Service, 309 p. Agriculture Handbook, no. 730.

EMPRESA BRASILEIRA DE PESQUISA AGROPECUÁRIA - EMBRAPA, 2009. Manual de análises químicas de solos, plantas e fertilizantes. 2nd ed. Brasília, DF: Embrapa Informação Tecnológica, 627 p.

FRENSCH, J. and HSIAO, T.C., 1993. Hydraulic propagation of pressure along immature and mature xylem vessels of roots of Zea mays measured by pressure-probe techniques. Planta, vol. 190, no. 2, pp. 263-270. http://dx.doi.org/10.1007/BF00196620.

GREGORIO, N.O., HERBOHN, J.L. and HARRISON, S.R., 2010. Guide to quality seedling production in smallholder nurseries. Visca: Visayas State University, 27 p.

HAASE, D.L. and DAVIS, A.S., 2017. Developing and supporting quality nursery facilities and staff are necessary to meet global forest and landscape restoration needs. Reforesta, vol. 4, no. 4 , pp. 69-93. http://dx.doi.org/10.21750/REFOR.4.06.45.

HALL, C.H., 2003. Manual on nursery practices. Kingston, Jamaica: Forestry Department, Ministry of Agriculture, 77 p.

HARRISON, S., GREGORIO, N. and HERBOHN, J., 2008. A critical overview of forestry seedling production policies and practices in relation to smallholder forestry in developing countries. Small-scale Forestry, vol. 7, no. 3-4, pp. 207-223. http://dx.doi. org/10.1007/s11842-008-9051-5.

HASANUZZAMAN, M., BHUYAN, M., NAHAR, K., HOSSAIN, M., MAHMUD, J., HOSSEN, M., MASUD, A., MOUMITA. and FUJITA, M., 2018. Potassium: a vital regulator of plant responses and tolerance to abiotic stress. Agronomy, vol. 8, no. 3, pp. 31. http:// dx.doi.org/10.3390/agronomy8030031.

HERRERA, A., TEZARA, W., MARÍN, O. and RENGIFO, E., 2008. Stomatal and non-stomatal limitations of photosynthesis in trees of a tropical seasonally flooded forest. Physiologia Plantarum, vol. 134, no. 1, pp. 41-48. http://dx.doi.org/10.1111/j.13993054.2008.01099.x. PMid:18444960.

HUNT, T., 2017. Growth analysis, individual plants. In: B. THOMAS, B.G. MURRAY and D.J.MURPHY, eds. Encyclopedia of applied plantsciences: plant physiology and development. 2nd ed. Oxford: Academic Press, pp. 421-429. http://dx.doi.org/10.1016/B978-0-12-394807-6.00226-4.

JAENICKE, H., 1999. Good tree nursery practices practical guidelines for research nurseries. Nairobi, Kenya: International Centre for Research in Agroforestry, $93 \mathrm{p}$.

KOZLOWSKI, T.T., 2002. Physiological-ecological impacts of flooding on riparian forest ecosystems. Wetlands, vol. 22, no. 3, pp. 550-
561. http://dx.doi.org/10.1672/0277-5212(2002)022[0550:PE IOFO]2.0.CO;2.

KREUZWIESER, J. and GESSLER, A., 2010. Global climate change and tree nutrition: influence of water availability. Tree Physiology, vol. 30, no. 9, pp. 1221-1234. http://dx.doi.org/10.1093/treephys/ tpq055. PMid:20581013.

LARSON, K.D., SCHAFFER, B. and DAVIES, F.S., 1993. Floodwater oxygen content, ethylene production and lenticel hypertrophy in flooded mango ( Mangifera indica L.) trees. Journal of Experimental Botany, vol. 44, no. 3, pp. 665-671. http://dx.doi. org/10.1093/jxb/44.3.665.

LARSON, K.D., SCHAFFER, B., DAVIES, F.S. and SANCHEZ, C.A., 1992. Flooding, mineral nutrition and gas exchange of mango trees. Scientia Horticulturae, vol. 52, no. 1-2, pp. 113-124. http://dx.doi. org/10.1016/0304-4238(92)90014-4.

LAVINSKY, A.O., SANT'ANA, C.S., MIELKE, M.S., ALMEIDA, A.A.F., GOMES, F.P., FRANÇA, S. and SILVA, D.C., 2007. Effects of light availability and soil flooding on growth and photosynthetic characteristics of Genipa americana L. seedlings. New Forests, vol. 34, no. 1, pp. 41-50. http://dx.doi.org/10.1007/s11056-006-9036-1.

LINDSTRÖM, A. and RUNE, G., 1999. Root deformation in plantations of container-grown Scots pine trees: effects on root growth, tree stability and stem straightness. Plant and Soil, vol. 217, no. 1/2, pp. 29-37. http://dx.doi.org/10.1023/A:1004662127182.

MCCULLY, M.E., 1994. Accumulation of high levels of potassium in the developing xylem elements in roots of soybean and some other dicotyledons. Protoplasma, vol. 183, no. 1-4, pp. 116-125. http://dx.doi.org/10.1007/BF01276819.

MARSCHNER, H., 2012. Mineral nutrition of higher plants. New York: Academic Press, $672 \mathrm{p}$.

MARTÍNEZ-ALCÁNTARA, B., JOVER, S., QUIÑONES, A., FORNER-GINER, M.Á., RODRÍGUEZ-GAMIR, J., LEGAZ, F., PRIMO-MILLO, E. and IGLESIAS, D.J., 2012. Flooding affects uptake and distribution of carbon and nitrogen in citrus seedlings. Journal of Plant Physiology, vol. 169, no. 12, pp. 1150-1157. http://dx.doi. org/10.1016/j.jplph.2012.03.016. PMid:22673030.

MEDRADO, J.S.M., DALZOTO, D.N., OLIZESKI, A. and MOSELE, S.H., 2002. Recuperação de ervais degradados. Colombo: Empresa Brasileira de Pesquisa Agropecuária, 6 p.

MESQUITA, C.M., REZENDE, J.E., CARVALHO, J.S., FABRI JÚNIOR, M.A., MORAES, N.C., DIAS, P.T., CARVALHO, R.M. and ARAÚJO, W.G., 2016. Manual do café: distúrbios fisiológicos, pragas e doenças do cafeeiro (Coffea arabica L.). Belo Horizonte: EMATER-MG, 62 p.

MIELKE, M.S., ALMEIDA, A.A.F., GOMES, F.P., AGUILAR, A.G. and MANGABEIRA, P.A.O., 2003. Leaf gas exchange, chlorophyll fluorescence and growth responses of Genipa americana seedlings to soil flooding. Environmental and Experimental Botany, vol. 50, no. 3, pp. 221-231. http://dx.doi.org/10.1016/ S0098-8472(03)00036-4.

MIELKE, M.S. and SCHAFFER, B., 2010. Leaf gas exchange, chlorophyll fluorescence and pigment indexes of Eugenia uniflora L. in response to changes in light intensity and soil flooding. Tree Physiology, vol. 30, no. 1, pp. 45-55. http://dx.doi.org/10.1093/ treephys/tpp095. PMid:19923194.

NARDINI, A., GREGO, F., TRIFILÓ, P. and SALLEO, S., 2010. Changes of xylem sap ionic content and stem hydraulics in response to irradiance in Laurus nobilis. Tree Physiology, vol. 30, no. 5, pp. 628635. http://dx.doi.org/10.1093/treephys/tpq017. PMid:20339142.

NOBEL, P., 2009. Physicochemical and environmental plant physiology. 4th ed. New York: Academic Press, 582 p.

ODDO, E., INZERILLO, S., LA BELLA, F., GRISAFI, F., SALLEO, S. and NARDINI, A., 2011. Short-term effects of potassium fertilization on the hydraulic conductance of Laurus nobilis L. Tree Physiology, 
vol. 31, no. 2, pp. 131-138. http://dx.doi.org/10.1093/treephys/ tpq115. PMid:21367746.

ORTUÑO, M.F., ALARCÓN, J.J., NICOLÁS, E. and TORRECILLAS, A., 2007. Water status indicators of lemon trees in response to flooding and recovery. Biologia Plantarum, vol. 51, no. 2, pp. 292-296. http://dx.doi.org/10.1007/s10535-007-0058-0.

OW, L.F., GHOSH, S. and YUSOF, M.L., 2019. Effects of waterlogged soil on $\mathrm{N}$-uptake by flood tolerant and sensitive containerised tree seedlings. Arboricultural Journal, vol. 41, no. 3, pp. 172-188. http://dx.doi.org/10.1080/03071375.2019.1642049.

PÉRET, B., DESNOS, T., JOST, R.J., KANNO, S., BERKOWITZ, O. and NUSSAUME, L., 2014. Root architecture responses: in search of phosphate. Plant Physiology, vol. 166, no. 4, pp. 1713-1723. http://dx.doi.org/10.1104/pp.114.244541. PMid:25341534.

PEZESHKI, S.R., 2001. Wetland plant responses to soil flooding. Environmental and Experimental Botany, vol. 46, no. 3, pp. 299-312. http://dx.doi.org/10.1016/S0098-8472(01)00107-1.

PEZESHKI, S.R. and DELAUNE, R.D., 2012. Soil oxidation-reduction in wetlands and its impact on plant functioning. Biology, vol. 1, no. 2, pp. 196-221. http://dx.doi.org/10.3390/biology1020196. PMid:24832223.

QUEIROZ-ALVES, L., LEAL, A., DALMOLIN, Â.C., SCHAFFER, B. and MIELKE, M.S., 2019. Photosynthesis and survival of young Carpotroche brasiliensis Endl. (Achariaceae) plants subjected to soil flooding. Forest Science, vol. 65, no. 6, pp. 670-674. http:// dx.doi.org/10.1093/forsci/fxz034.

R CORE TEAM, 2015 [viewed 5 February 2020]. R: a language and environment for statistical computing [software]. Vienna: $\mathrm{R}$ Foundation for Statistical Computing. Available from: https:/| www.R-project.org/

RENNENBERG, H., DANNENMANN, M., GESSLER, A., KREUZWIESER, J., SIMON, J. and PAPEN, H., 2009. Nitrogen balance in forest soils: nutritional limitation of plants under climate change stresses. Plant Biology, vol. 11, suppl. 1, pp. 4-23. http://dx.doi.org/10.1111/j.1438-8677.2009.00241.x. PMid:19778364.

ROLIM, S.G., PIÑA-RODRIGUES, F.C.M., PIOTTO, D., BATISTA, A., FREITAS, M.L.M., BRIENZA JUNIOR, S., ZAKIA, M.J.B. and CALMON, M., 2019 [viewed 5 February 2020]. Research gaps and priorities in silviculture of native species in Brazil [online].
São Paulo: WRI Brasil. Working Paper. Available from: https:// wribrasil.org.br/pt/publicacoes

SHEN, J., YUAN, L., ZHANG, J., LI, H., BAI, Z., CHEN, X., ZHANG, W. and ZHANG, F., 2011. Phosphorus dynamics: from soil to plant. Plant Physiology, vol. 156, no. 3, pp. 997-1005. http://dx.doi. org/10.1104/pp.111.175232. PMid:21571668.

SILVA, A.P.M., MARQUES, H.R., DOS SANTOS, T.V.M.N., TEIXEIRA, A.M.C., LUCIANO, M.S.F. and SAMBUICHI, R.H.R., 2015. Diagnóstico da produção de mudas florestais nativas no Brasil. Brasília: Instituto de Pesquisa Econômica Aplicada, 58 p.

SILVA, A.P.M., SCHWEIZER, D., MARQUES, H.R., TEIXEIRA, A.M.C., SANTOS, T.V.M.N., SAMBUICHI, R.H.R., BADARI, C.G., GAUDARE, U. and BRANCALION, P.H.S., 2017. Can current native tree seedling production and infrastructure meet an increasing forest restoration demand in Brazil? Restoration Ecology, vol. 25, no. 4, pp. 509-515. http://dx.doi.org/10.1111/rec.12470.

SOUZA, A.F., ANDRADE, A.C.S., RAMOS, F.N. and LOUREIRO, M.B., 1999. Ecophysiology and morphology of seed germination of the neotropical lowland tree Genipa americana (Rubiaceae). Journal of Tropical Ecology, vol. 15, no. 5, pp. 667-680. http:// dx.doi.org/10.1017/S026646749900108X.

VAHL, L.C., 1991. Toxidez de ferro em genótipos de arroz irrigado por alagamento. Porto Alegre: Faculdade de Agronomia, Universidade Federal do Rio Grande do Sul, 173 p. Tese de Doutorado em Ciência do Solo.

VOESENEK, L. and BAILEY-SERRES, J., 2015. Flood adaptive traits and processes: an overview. The New Phytologist, vol. 206, no. 1, pp. 57-73. http://dx.doi.org/10.1111/nph.13209. PMid:25580769.

WANG, G.B. and CAO, F.L., 2012. Formation and function of aerenchyma in baldcypress (Taxodium distichum (L.) Rich.) and Chinese tallow tree (Sapium sebiferum (L.) Roxb.) under flooding. South African Journal of Botany, vol.81,pp. 71-78. http://dx.doi.org/10.1016/j.sajb.2012.05.008.

WIGHTMAN, K.E., 1999. Good tree nursery practices: practical guidelines for community nurseries. Nairobi, Kenya:International Centre for Research in Agroforestry, 95 p.

WILKINSON, K.M., LANDIS, T.D., HAASE, D.L., DALEY, B.F. and DUMROESE, R.K., 2014. Tropical nursery manual: a guide to starting and operating a nursery for native and traditional plants. Washington: Department of Agriculture, Forest Service, 378 p. Agriculture Handbook, no. 732. 